\title{
ARE STAKEHOLDERS IN SLOVAKIA READY FOR COMMUNITY-LED LOCAL DEVELOPMENT? CASE STUDY FINDINGS
}

\author{
Monika Bumbalová1, Ivan Takáč², Jela Tvrdoňováa ${ }^{3}$, Martin Valach ${ }^{4}$
}

Received 19 February 2016; Accepted 30 June 2016

\begin{abstract}
In the EU new programming period 2014-2020 the Leader approach become part of community-led local development (CLLD). Under Slovak conditions, partnerships, which intend to get the legal status of local action group (LAG), are currently in the process of preparing and formulating their CLLD Strategies. Leader approach is characterised by 7 principles, which should be horizontally presented throughout the implementation process. The multilevel governance presented in the implementation of Leader approach includes the management and implementation of rural development programme, through which the Leader is implemented, as well as, formation of LAGs, as the mediators of the approach at local level. Both levels may have supporting or constraining effects on the application of Leader principles in the Leader delivery. The paper focuses on analysing the differences between theory and practice in the conditions of the Slovak Republic when answering the evaluation question: Are stakeholders in Slovakia ready for community led local development? To answer the question, six LAGs were assessed using the focus group as the assessment tool. Representatives of the national authorities were interviewed in order to complete the picture of the evaluated topic. The study pointed out several shortcomings in basic preconditions allowing smooth application of the CLLD.
\end{abstract}

Keywords: Leader approach, community- led local development, local action group, rural development

Abstrakt: $V$ novom programovom období 2014- 2020 sa prístup Leader stal súčast'ou tzv. miestneho rozvoja vedeného komunitou (MRVK). V podmienkach Slovenska, partnerstvá, ktoré sa uchádzajú o štatút MAS, sú momentálne v procese tvorby stratégie MRVK. Leader je $v$ zásade charakterizovaný 7 znakmi, ktoré by mali byt' prierezovo prítomné $v$ rámci implementačného procesu. Viacúrovňové vládnutie,

\footnotetext{
${ }^{1}$ Ing. Monika Bumbalová, PhD., Slovak University of Agriculture in Nitra, Tr. Andreja Hlinku 2, 94974 Nitra, Slovakia; e.mail: monika.bumbalova@uniag.sk

2 Ing. Ivan Takáč, PhD., Slovak University of Agriculture in Nitra, Tr. Andreja Hlinku 2, 94974 Nitra, Slovakia; e-mail: ivan.takac@uniag.sk

${ }^{3}$ Ing. Jela Tvrdoňová, PhD., The European Network for Rural Development - Evaluation Helpdesk,Boulevard Saint Michel 77-79, B-1040 Brussels, Belgium; e-mail: jela@ruralevaluation.eu

${ }^{4}$ Mgr. Martin Valach, PhD., Slovak University of Agriculture in Nitra, Tr. Andreja Hlinku 2, 94974 Nitra, Slovakia; email: martin.valach@uniag.sk
} 
ktorým sa Leader realizuje, je tvorené jednak riadením a uplatňovaním programu rozvoja vidieka, ktorý tvorí rámec pre implementáciu prístupu, a jednak miestnymi akčnými skupinami (MAS), ako nositel'mi prístupu na miestnej úrovni. Tieto úrovne môžu mat' pozitívny, ale aj negatívny vplyv na uplatňovanie znakov prístupu počas jeho realizácie. Príspevok sa zaoberá rozdielmi medzi teóriou a praxou v podmienkach Slovenskej republiky pri hladaní odpovede na otázku: "Sú aktéri na Slovensku pripravení na uplatňovanie miestneho rozvoja vedeného komunitou?". $\mathrm{Na}$ zodpovedanie tejto otázky bola použitá metóda fokusových skupín, ktorú sme aplikovali v 6 MAS. Chýbajúce informácie sme doplnili prostredníctvom riadených rozhovorov s predstavitel'mi inštitúcií na národnej úrovni. V rámci štúdie bolo identifikovaných niekol'ko nedostatkov $v$ základných predpokladoch, ktoré by mali zabezpečit' bezproblémový prechod na MRVK.

Klúčové slová: prístup Leader, miestny rozvoj vedený komunitou, miestna akčná skupina, rozvoj vidieka

\section{Introduction}

In the year 2014, all policies of the EU including the Rural Development Policy entered new programming period. This programming period has brought new design and instruments to support the local development. The Leader approach, which has been originally introduced as rural development laboratory (1991 - 1993 as Leader I) and which was considered as the essence of EU rural development policy (Kovách, 2000), has evolved into widely used rural development instrument within several programming periods (1994-1999 as Leader II, 2000-2007 as Leader Plus and 2007-2013 as Leader Axis) (Owen - Vercruysse, 2014). Since the 1990s, much of the focus in rural development theory and practice has been on local action and endogenous development approaches, exemplified the Leader programme characterised by targeted partnership intervention within new forms of multi-level and multi-scalar governance (Gkartzios Scott, 2013). Kovách (2000) believes that Leader might become the dominant principle and practice of European rural development policy and thereby, but conditionally, fundamental to the European response to globalization.

Since its start, the Leader approach has provided rural communities in the EU with a method for involving local partners in shaping the future development of their designated area (European Commission, 2015). It has represented one of the most influential sets of activities to address the spirit of mobilizing countryside, through focusing on endogenous potential (Dax et al., 2013), addressing aspatial variations in territorial assets (Copus et al., 2011) and by capturing of exogenous impulses, which can foster the development of the local area (Nevědel - Horák, 2015). Awareness and acceptance of the deeper philosophy behind Leader has been gaining ground so that it is increasingly acknowledged as a powerful tool for the promotion of rural development in general and for the animation of local, collective action (Esparcia Pérez, 2000). For this process, the presence of local initiatives, such as local action groups, was a basic precondition (Volk Bojnec, 2014). LAGs in fact work as carriers of Leader approach in concrete territories, mediating the local development through the local development strategies (LDS) (Bumbalová et al., 2015).

Critical to the socio-economic development process are those institutions, actors and networks that have the capacity to link businesses, communities and institutions involved in governance at a variety of scales (Shucksmith, 2012). The success of Leader is, therefore, based largely on its central "bottom up" principle, which enables and ensures the local participation and empowerment, continued stakeholder engagement via public - private partnerships, community 'buy-in' to the delivery of programmes, and innovative and effective interventions (Miller, 2014).

The approach itself is primarily defined by 7 key principles, which are: area - based local development strategies, bottom - up elaboration and implementation of strategies, local public private partnerships - local action groups, integrated and multi-sector actions, innovation, cooperation and networking (EC Regulation 1698/2005). Features of the leader phenomenon can be traced to preceding processes and conditions such as politico-administrative decentralization, actor and policy networking, and the dynamics and reconversion of social capital (Kovách, 2000). 
These principles define the Leader approach, measure the degree of its implementation and evaluate its impact. They are also at the core of the design of the Community-Led Local Development (CLLD) (Owen - Vercruysse, 2014), which forms an umbrella for implementation of the rural development policy, including Leader, in the period 2014 - 2020. CLLD represents a way of delivering multi-fund interventions through a place-specific focus, enabling targeted and innovative community-led projects (Miller, 2014). Using CLLD it is possible for a single LDS to be supported by several EU funds (known as multi-funded CLLD). This will enable LAGs (rural, fisheries and urban) to fully explore the potential of the CLLD approach, to comprehensively integrate local needs and solutions and reinforce the links between rural, urban and fisheries areas (European Commission, 2015). Consequently, Peters (2013) defines the CLLD as a particularly powerful tool, especially in times of crisis, showing that local communities can take concrete steps towards forms of economic development, which are smarter, more sustainable and more inclusive, in line with the Europe 2020 strategy. According to Owen - Vercruysse (2014) the CLLD encourages a more integrated territorial approach across the different European Structural Investment Funds (ESI Funds) towards local development.

When linking the CLLD with the Leader, Miller (2014) claims that CLLD is both a continuation and an extension of the Leader approach. This close link, on the one hand, enables local communities, already involved in the Leader approach, to smoothly adapt their operations and management and continue in the development of the territory within the new programming period. On the other hand, as the 7 key principles of the approach, remained an inevitable part of the implementation, even under these modified conditions, it is necessary that local communities are ready to comply with the stated criteria, which means they are ready to operate within the new programming period.

As Leader Axis in the previous period, also the CLLD is the subject of evaluation (European Commission, 2013). While the assessment of CLLD strategy's contributions to the EU rural development objectives is a compulsory task (European Commission, 2015), a review of the Leader practice argues that many available studies apply a limited perspective of selfevaluation and reflection on Leader activities (Dax - Oedl-Wieser, 2016). The evaluation of Leader method, however, can be seen as good practice (Tvrdoňová, 2009).

This paper aims to contribute to the approaches in evaluation of Leader method. It focuses on the assessment of Leader delivery as prepared and implemented by stakeholders and its effects on the practical implementation of Leader principles at the national and local levels. It also looks at the readiness of local action groups in Slovakia to adopt the new philosophy of CLLD based on primary data collected at seven Slovak local action groups.

\section{Methodology}

The rationale behind choosing the research on the readiness of stakeholders is the existence of new instrument appearing in the EU funding portfolio to support the territorial cohesion. This instrument brings a lot of novelties compare to its predecessor - Leader, and its implementation will require a range of new capacities. Therefore, the overall research question (also presented in the title of the article) is: To what extent are stakeholders in Slovakia ready for the successful application of the Community-led local development?

Having in mind the multi-level character of Leader implementation (national and local) and in order to answer the research question, the team has chosen following stakeholders responsible for Leader implementation for conducting the research:

- At the national level:

o representatives of Managing Authority, responsible for programming of the Leader approach, e.g. selection of eligible measures, budgets, selection of LAGs, etc.,

o representatives of Paying Agency, responsible for implementing the Leader, while ensuring the smooth project selection, implementation and finalising, including the payment and monitoring procedures.

- At the local level - local action groups (LAGs), which implemented the Leader already in 
the programming period 2007-2013 and operated in different socio-economic conditions of various Slovak regions. In total, 7 LAGs have been selected for the purpose of the research (Figure 1).

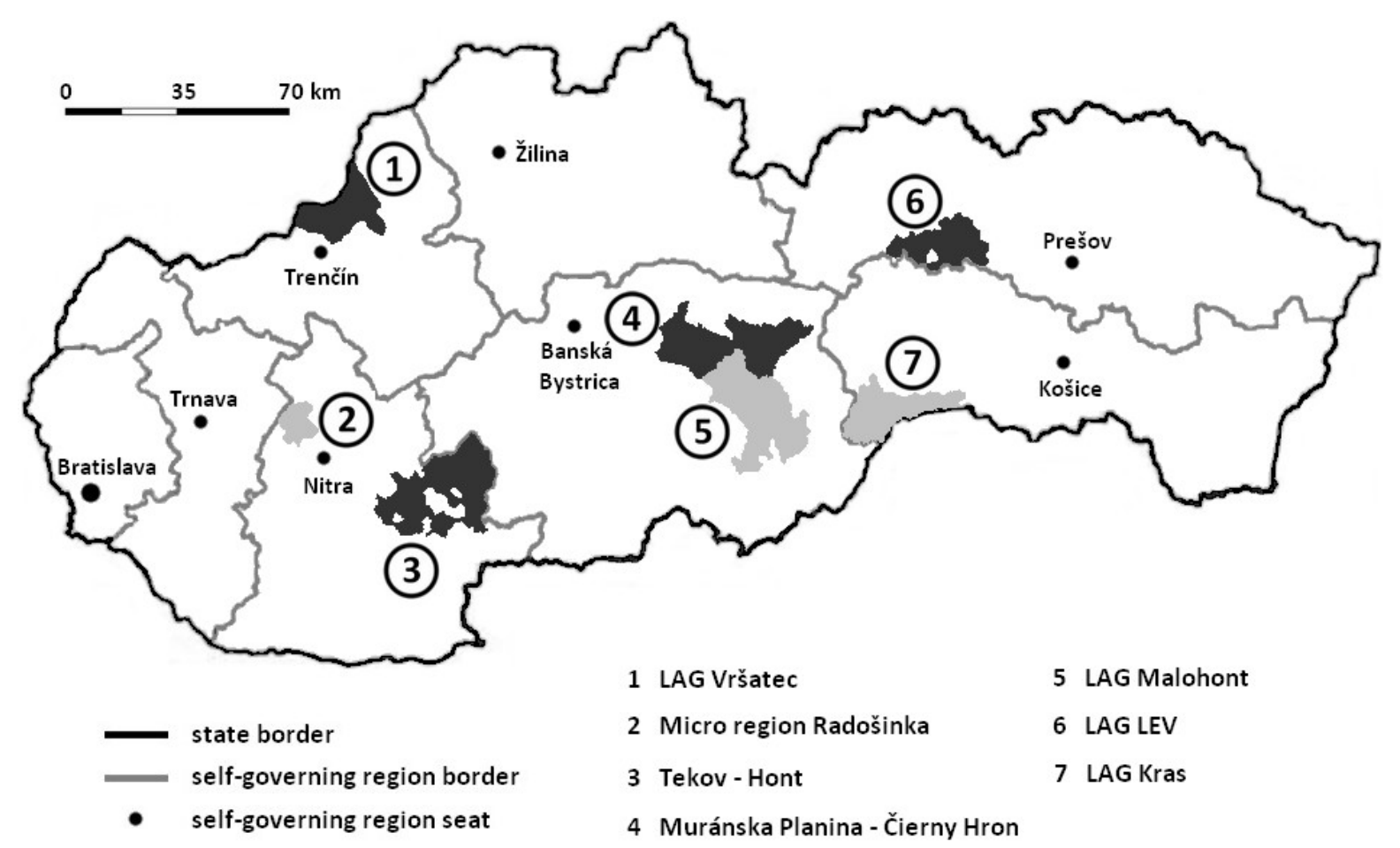

Fig 1. Location of Visited LAGs. Source: own processing

To answer the above research question, the team has developed the evaluation framework, which was on one side defined by seven Leader/CLLD principles as stated in the EC Regulation $1698 / 2005$ and on the other side with the steps of Leader/CLLD delivery mechanism at the national (RDP) and local (LAG) levels (Bumbalová, 2015). Seven Leader principles are:

- bottom up approach in decision making procedures in the LAG territory, namely in design and implementation of local strategy,

- public-private partnership, which governs the territory,

- area based strategies, which should address the need of the whole LAG area,

- integrated and multi-sector actions in strategies,

- support for networking inside of LAG territory and outside among LAGs,

- preparation and implementation of cooperation projects between local action groups,

- fostering the innovation across all activities of the LAG.

The delivery steps at national and local level are summarised below.

National level:

- ensuring the capacity building to prepare LAGs,

- call for proposals for LAGs,

- LAGs selection and contracting

- ensuring capacity building for LDS implementation,

- implementation of LDS - project selection and contracting,

- implementation of LDS - project implementation and finalising, 
- monitoring,

- evaluation of LAGs and LDS.

Local level:

- capacity building at LAG,

- design and approval of LDS,

- application process and contracting LDS,

- running the LAG,

- animation of the territory,

- capacity building \& training during LDS implementation,

- implementation of LDS \& call for proposals,

- implementation of LDS, project selection and approval,

- monitoring of projects,

- evaluation and self-assessment of LDS.

Identified steps have been paired with 7 principles in matrix format for each level separately. Matrix format has allowed identifying the key success factors (benchmarks), which have been set up for every step of the delivery mechanism at both levels (for details see Bumbalová et al., 2015). The identified steps and key success factors have been used as the basis to design the evaluation tools: interviews and focus groups. The interview has been designed to collect data at the national (RDP) level. Focus groups have been used to collect the information in the local action groups: Radošinka Microregion; Tekov-Hont; LAG Vršatec; LAG LEV; Partnership Muránska Planina Čierny Hron; LAG Kras and LAG Malohont. The visited LAGs were chosen to geographically cover majority of regions in Slovakia (Fig. 2).

Surveyed groups were composed of 81 persons in total, while men made up a little over half of those in attendance (53\%). Focus groups participants (local stakeholders) represented following sectors: mayors (44.44\%); NGOs (18.51\%); beneficiaries $(12.37 \%)$; private sector $(8.64 \%)$; LAG management staff $(8.64 \%)$ and civil associations $(7.40 \%)$.

Additionally, three interviews covering managing authority and paying agency took place in order to complete the necessary information.

Research findings were the basis for formulation conclusions and recommendations for the future application of Leader/CLLD delivery so that the Leader method is maintained and developed in the context of the Slovak Republic.

\section{Results and Discussion}

\section{Overview of Leader Approach Implementation in the Programming Period 2007-2013}

The Leader approach was first introduced in Slovakia during the EU programming period 2007 2013 as Leader Axis in the Rural Development Programme of the Slovak Republic 2007 - 2013 (RDP SK 2007 - 2013). Leader approach has covered the implementation of local development strategies, running of local action groups/acquiring skills/ animation the territory and the cooperation projects among LAGs in SK and the EU. Local development strategies were implemented via Axis 3 ("Quality of life in rural areas and diversification of the rural economy") of the RDP SK, namely the following measures: diversification into non-agriculture activities (M311), encouragement of tourism activities (M313), basic services for economy and rural population (M321), village renewal (M322) and training and information (M331). As for preparation of LAGs and development of LDS, the measure of Axis 3: Skills acquisition, animation and implementation has been used. Implementation of the axis 4 of the RDP SR 2007 - 2013 was in Slovakia supported by 79 mil. $€$, representing $3.13 \%$ of contribution from the EAFRD (European 
Commission, 2013).

In Slovakia within the programming period $2007-2013$, there were 29 LAGs approved. These LAGs included 617633 inhabitants (11.44\% of the total population) and covered the area of $9023.59 \mathrm{~km}^{2}$ (18.4\% of the country). In total 543 municipalities participated in LAGs representing nearly $19 \%$ of all municipalities. An average Slovak LAG would, therefore, include 20712 inhabitants, covers the area of $310.2 \mathrm{~km}^{2}$ and involve almost 19 municipalities. The mere coverage of the rural area, however, does not represent any proof of its effectiveness and implications on the rural society. Nevertheless, based on a series of case studies in many EU Member States it can be concluded that internal processes, regional perspectives and socioeconomic activities have evolved (Dax - Oedl-Wieser, 2016).

Implementation of local development strategies has claimed 63 mil. $€$, and the running of LAGs consumed 12 mil. $€$. The national and trans-national cooperation was funded by 3.7 mil. $€$. Thematically the projects in the programming period 2007-2013 focused mainly on tourism, agrotourism, reconstruction and modernization of public spaces, parks and leisure activities (playgrounds and bike paths). The average amount of accepted eligible costs for one project was $42000 €$.

When assessing the achievements of the approach by using the Common Monitoring and Evaluation Framework for rural development and consequently, the common monitoring indicators, the following target output indicators have been exceeded: the number of supported beneficiaries (211.2\% of target), the number of projects financed by LAGs (225.6\% of target) and total population of supported LAGs (146.65\% of target) (National Agricultural and Food Centre, 2007 - 2014).

The total number of projects financed by LAGs was 1128 . Out of these projects, the highest portion (54\%) was financed through the $M 321,39 \%$ of projects through $M 322,5 \%$ of projects through $\mathrm{M} 313,1.9 \%$ of projects through $\mathrm{M} 331$ and $0.1 \%$ projects through $\mathrm{M} 311$ (Fig. 2). In total there were 778 final beneficiaries, while 717 (92\%) come from the public sector, 31 are legal persons and 30 physical persons.

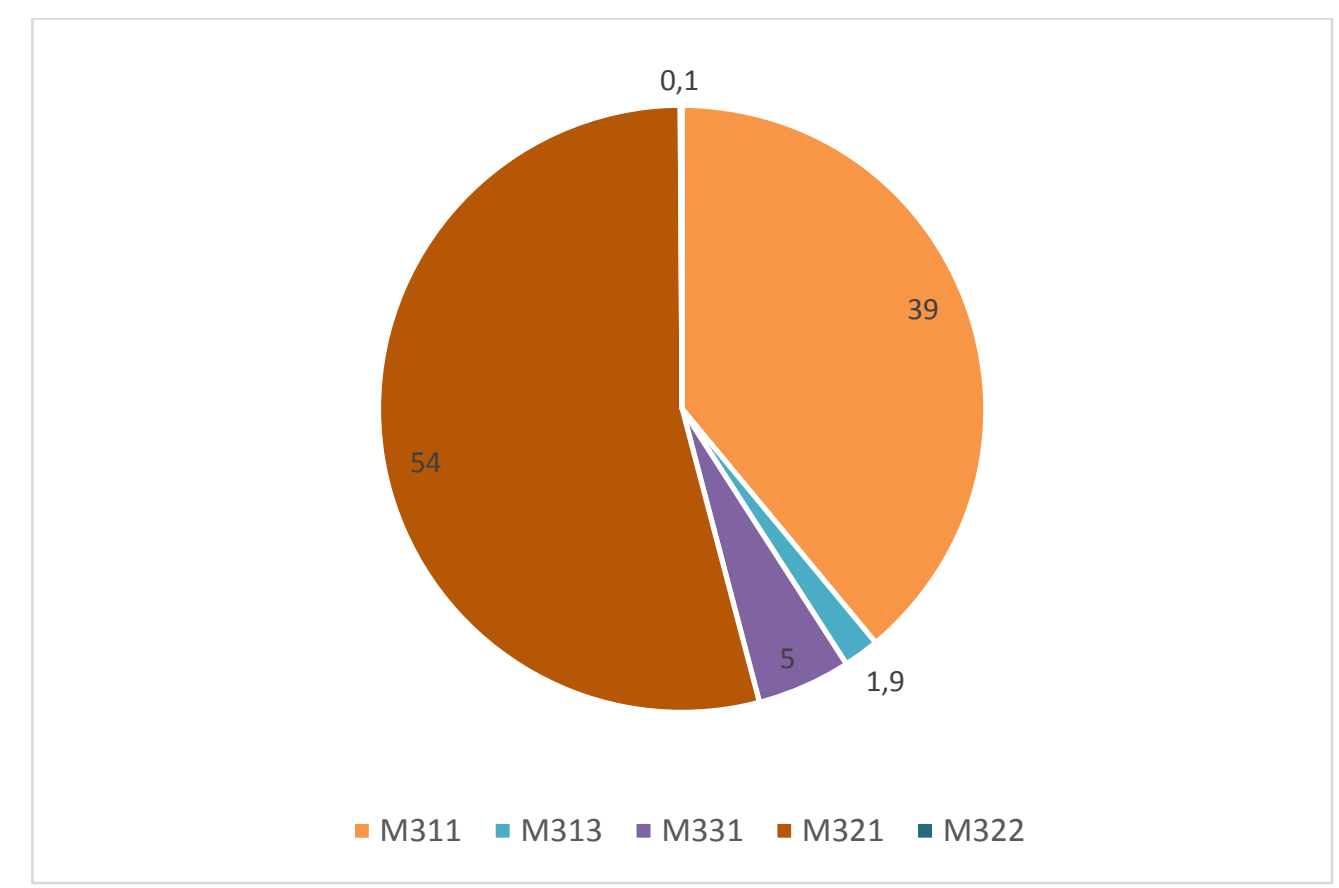

Fig 2. Share of Implemented Projects by LAGs According Axis 3 Measures (in \%). Source: National Agricultural and Food Centre, 2007 - 2014 


\section{Ensuring the Application of Leader Principles with the Leader Delivery at National Level}

The defined key success factors (benchmarks) for the successful implementation of Leader approach, such as capacity building opportunities for future and existing LAGs, call for proposals, selection of strategies, contracting of LAGs, implementation, monitoring and evaluation of strategies have been compared with the empirical data collected in the field research. These comparisons have been used to identify how the Leader delivery mechanism is fostering/weakening the application of Leader principles/method in the Leader approach implementation. Findings have indicated the potential opportunities and threats in smooth application of the CLLD approach by involved stakeholders in programming period 2014 - 2020. Findings regarding step in delivery mechanism are described below.

As for capacity building for future LAGs, Shucksmith (2000) claimed that discourses of endogenous development tend to emphasise building the capacity not of individuals but of communities as territories. Prior to LAGs selection and contracting, the following characteristics were identified as benchmarks:

- $\quad$ open access to events and training sessions for representatives of all sectors and spheres,

- promotion of linkages between local development actions,

- clear stakeholder analysis and audit of resources,

- definition of rules, measures, innovation and promotion of collaboration with more experienced entities.

The findings have shown that the RDP managing authority (MA) has collaborated with a large number of stakeholders when providing educational and training events, face-to-face meetings, online tools and all the support, which has aimed to help the LAGs with developing their strategies. This process included a new role for the state as coordinator, manager or enabler, rather than as provider and director (Shucksmith, 2012). The LAGs representatives, however, stated that this assistance from MA came with delay. Fortunately, in several cases, the Leader type partnerships have been already operating; therefore, identifying "natural" leaders and provision of capacities did not require a lot of time and effort. Additionally, lack of use of wider innovative analytical tools to evaluate local assets and to set up priorities (e.g. stakeholder analysis, concept mapping, GIS and mapping of local assets, etc.) was identified as a shortcoming of this stage.

As for designing the call for proposals to select LAGs, the stakeholders have confirmed that this step was clearly formulated, and partly designed in participatory way. The call has provided enough time for strategy elaboration, and encouraged multi-sector strategy design reflecting the local needs. The call has also provided a list of "potential" partnerships. Paying agency (PA) did not have direct influence on the design of the call for proposals; however, it has participated in the strategy evaluation and contributed considerably to professional opinion while coordinating various PA's branches with different field expertise located in different regions in Slovakia. On the other hand, the participation of other stakeholders such as beneficiaries and nonbeneficiaries, public and private stakeholders, farmers or civil society, as well as the transparency during the process of call preparation was often omitted.

Selecting and contracting LAGs based on their local development strategies (LDS) was supposed to reflect:

- the national needs,

- $\quad$ encourage the development process in the under-represented areas (territorywise as well as sector-wise), and

- $\quad$ provide support proportionally to the population.

The selection committee has seen the innovative features employed in strategy design and implementation and application of existing resources as strengths. Support of networking and 
cooperation among LAGs was also appreciated in the selection procedure. In reality, the criteria, which were dominantly influencing the decision-making (beside the mandatory ones), were: (1) the share of private-investments, (2) the socio-economic impact of the LDS, (3) the quality of partnerships and the overall strategy, (4) the eligibility costs supported by public funds (the lower the better). In contrary, the criteria, which were missing during the selection process, were e.g. experience in the community development, degree of diversity of the members, inclusiveness of minority groups like Roma community or disadvantaged groups of population, gender equality, etc. Similar situation, however, could be observed in Austrian context, where Dax - Oedl-Wieser (2016) claimed that despite the strong evidence that gender equality and social diversity boost sustainable economic growth in rural areas, all social issues are still subordinate to economic interests. This could be considered as weakness regarding readiness of stakeholders to implement the CLLD in the future.

After selecting LAGs, another "round" of capacity building is required. This stage should offer:

- the training for all involved stakeholders in compulsory matters,

- provide the feedback to LAGs to improve the strategy design and implementation,

- ensure transfer of good practices and mediate the cooperation,

- networking among LAGs at home and abroad.

Findings have shown that the capacity building after LAGs selection was conducted as rather formal exercise or on the individual basis in form of personal visits, email or phone communication. In case of trans-national cooperation, the national authorities have shown a low commitment and left its implementation with LAGs, which did not have sufficient capacities create important linkages with the LAGs in the EU Member States. The lack of support from the side of MA is seen as weakness also by Shucksmith (2012), who claims that while support can come from foundations, universities and others, it is not clear who else might provide capacity-building on the scale required and in a systematic way apart from government, whose enabling and fostering role is crucial.

Implementation of LDS via project selection, contracting and finalizing was identified as important step of the delivery mechanism at the national level. Benchmarks of this step are:

- selection of projects must be in line with the objectives of the programme,

- balanced participation of all sectors, which roles are clearly defined,

- the possibility of non-financial contribution and a space for continuous networking,

- high transparency and clear rules in all the actions in the territory are required inevitably.

The practical implementation of this step seems to be primarily bound by the national and regional accountability rules not working in its favour. Additionally, frequent changes in legislation had a negative impact while increasing the level of uncertainty and administrative workload at implementation level. The fact that the communication and cooperation between national authorities and LAGs has improved can be seen as a positive aspect of the implementation phase. Moreover, with more implemented projects, LAGs gained more experience and were able to deal with numerous situations without assistance from MA. This approach can be considered as a failure.

Monitoring, as an integral part of the delivery mechanism, should possess following features:

- clear monitoring criteria reflecting the uniqueness of the territory,

- presence of self- monitoring e.g. via local monitoring committee,

- usage of tools for public feedback,

- ensuring the innovative character of projects and 
- involvement in networks.

In reality, the research has observed the compliance with the EU Common Monitoring and Evaluation Framework, namely the application of double-step monitoring - at LAG level and, subsequently, at the Agricultural Paying Agency level (double-check of the compliance with financial requirements).

Monitoring is typically going hand in hand with evaluation. When thinking about an ideal evaluation process, following attributes need to be presented:

- participation of beneficiaries as well as non-beneficiaries,

- peer -to- peer evaluation (participation of other LAGs),

- usage of appropriate technique, while evaluating multiplier effects, side effects and long term effects,

- dissemination and sharing of results, best practices, success and failures.

Several shortcomings, however, could be identified in the practice. The whole evaluation process seems to be rather formal. MA declared that since the design of the Leader evaluation system is mainly bounded to the RDP legislation and standards, the room to influence the overall quality of the LAG's evaluation systems (e.g. fostering more the use of participatory techniques) is almost zero. Additionally, lack of human capacity and complexity of programme was seen as a weakness and as an excuse at the same time. This situation can be caused by the lack of political awareness of the Leader approach and so evaluation is addressed only superficially. All these aspects decreased the perceived level of readiness of local stakeholders for the new programming period and CLLD.

Regarding the follow up of the evaluation results the research has found that evaluation findings are published on-line in ex-ante, ex-post and mid-term reports, in order to target as many interested stakeholders as possible. Moreover, the dissemination activities predominately occur during the informal and personal meetings between different actors.

\section{Ensuring the Application of Leader Principles with the Leader Delivery at Local Level}

The second part of the research has concerned local level. Similarly to the first part of the research, the key success factors (benchmarks) have been identified as the basis for designing the focus groups. Consequently, the information collected via primary research (focus groups) has been compared with the identified benchmarks. The findings are described according to the steps of the Leader delivery mechanism at local level, whereas the negative aspects were perceived as obstacles in transition to the CLLD.

The process of implementing Leader approach at the local level starts with the capacity building in the territory. Esparcia Pérez (2000) argues that it cannot be said that leader has been responsible for bringing about a generalized dynamic of bottom-up participation in rural areas, though significant progress is being made in this direction. The most important features of successful capacity building appeared to be:

- presence of local leaders,

- creation of database of potential stakeholders, together with clear complex information about the territory,

- common understanding of innovation.

Based on the collected information, those were mostly mayors who initiated the public meetings for strategy preparation and Leader awareness rising. This statement is supported also by the research conducted by Gasior-Niemiec - Pawlowska (2014) who identify the representatives of public sector being the architect for local development. McAreavey (2009) also stresses out the dominance of public sector and their unwillingness to transmit the power. 
After awareness rising in the territory, the process of designing, approval and contracting of LDS come to place. The key success factors of smooth introduction of this step do not significantly differ from those identified at the national level:

- inclusiveness and reaching consensus among all stakeholders,

- balance between sectors,

- addressing local needs and specificities,

- innovative approach and

- room for transfer of knowledge and mutual learning among LAGs.

During the focus groups, LAG stakeholders almost unanimously stated, that even though the process of LDS creation had been open for everyone, stakeholders from private sector had been underrepresented (besides maintaining the rule of $50: 50^{5}$ ). The reasons were administrative and bureaucratic complexity of project implementation, which had discouraging effect and limited presence of measures eligible for the private beneficiaries in the programming period $2007-2013$. The importance of the private sector representatives for the area is undeniable as Shucksmith (2012) states that entrepreneurs in rural areas have just as strong aspirations to grow their businesses as urban entrepreneurs, but there are many challenges and difficulties facing rural businesses, notably poorer infrastructure, distant services, planning restrictions and labour shortages. All stakeholder, however, expressed hope for improving this situation in the new programming period due to wider portfolio of eligible activities and also due to gained experiences and visible positive effects of already implemented projects. Similar findings were described by Dax et al. (2013), who argue that the implementation of Leader in this period falls far behind its potential to beneficially impact rural regions; hence it should be an object of critical debate in the reform of the Common Agricultural Policy and rural development measures.

Regarding reflecting local needs and specific features of the territory in the LDS it seems, that LAGs used this opportunity well e.g. the projects oriented on regional branding needed careful consideration and recognition of unique aspects in the area. Moreover, in some cases they can be used as examples of the best practices of cooperation and innovativeness. Because as Dax Oedl-Wieser (2016) argue the notion of social innovation is widely recognized as of central importance to the aims of Leader. Social innovation is not an aspatial activity, but is therefore intrinsically linked to territory. On the other hand, there was little evidence that innovation was strategically addressed, although organizational support already exists, for example the European Innovation Partnership.

As a weak point, can be seen the fact, that interregional strategy for the whole Slovakia is absent. In contrary, the area-based principle that coordinates the whole territory would enhance and create the spill over effect across the country.

LAGs have also pointed out that the financial support for LAG operations was the same for all LAGs regardless the number of municipalities involved in the LAG. To illustrate this, there was a big discrepancy in size of LAGs, e.g. the largest LAG in Slovakia was composed of 47 municipalities (LAG Malohont) and involved many beneficiaries, while the smallest one was formed only by 4 municipalities (LAG of Microregion Teplička) with relatively small number of beneficiaries and both have received the same budget for strategy implementation. Even without deeper analysis, it is obvious, that the transaction costs to manage the territory of the first LAG were significantly higher than in case of the second one. This created the comparative advantage for smaller LAGs, and negatively affected the essence of the Leader approach to cover as much of rural areas as possible.

Following two steps of delivery mechanism, in particular running of LAG and animation of the territory, can be described within one paragraph as they are mutually linked with each other. Key success factor for these two stages are:

\footnotetext{
5 The formal rule of composing LAG is that maximum $50 \%$ of the LAG members must represent the public sector and minimum $50 \%$ of $L A G$ members must come from private or third sector.
} 
- everyone, who is interested, is allowed and encouraged to participate (sector-wise, areawise, gender-wise, etc.),

- stakeholders should operate in such environment, where they can easily approach LAG representatives,

- LAG can easily interact with other LAGs nationally or internationally,

- specific feature of territory animation is good facilitation of interaction between different institutional levels horizontally and vertically.

The research has shown, that the openness of LAGs towards the inhabitants in the territory reached very good level, what is proven by a high level of trust observed within investigated LAGs. To confirm this, there are partnerships, which were not awarded the formal statute of LAG (and consequently the financial support), however, they kept operating, while using their own budget created by pooling resources from different stakeholders in the area.

Slightly different story can be told about cooperation between LAGs. In spite the cooperation exists to some extent (mostly with LAGs from abroad, especially from neighbouring countries with no language barrier), the competition among the Slovak LAGs prevails the cooperation. Since the Leader approach in Slovakia is applied in limited number of territories, it represents rather "elite" type of approach with a lot of competition among potential territories. This situation lowers the level of readiness of Slovak local actors for CLLD. Effective usage of marketing tools is additional aspect identified as a weakness and at the same time as an opportunity for the territory animation. Some measures to improve the situation should be taken at the national level.

Stages dealing with implementation of LDS, call for proposals, project selection and approval, are subsequent phases of the delivery mechanism. The call for proposals should be ideally accompanied by the fact that:

- all the potential stakeholders are aware of its opening,

- consultancy is offered to them.

When talking about the project selection and approval, following aspects represent key success factor:

- the balanced selection of projects (sector-wise, size-wise),

- putting emphasis on project promoting innovation, usage of local resources, cooperation and networking and projects having multiplier effects.

The field research showed that participation of different stakeholders did not start ideally, however, it improved over the time. Selection process followed the formal criteria and all stakeholders were aware of them. A positive side was also that communities have shown, despite diverse opinions, ability to overcome differences and develop coherent and unified visions for the implementation of development projects. Furthermore, common implementation of LDS stimulated the feeling of belonging and ownership among the stakeholders. Strong leaning towards public projects can be seen as a negative aspect; however, it has brought more significant impact on the community as such. The reasons for this situation were mentioned earlier in the text, here we would like to add also the complexity and ambiguity of public procurement process in the Slovak conditions. The current legislation makes it impossible to prefer local producers, what is in direct contradiction with the objective to support local economy, local producers and suppliers (Grambličková et al., 2013). The negative impact of this legislation is crosscutting the whole implementation process. Change of legislation at the national level is the only way how to modify this situation, but keeping in mind weak "voice" and negotiating position of LAGs, there is little hope, this issue can be altered in the near future.

Emphasis on innovation is the last aspect, which should be addresses here. When innovation is perceived as something new for the territory, then certain level of innovativeness was presented in all visited LAGs. Nevertheless, what should be pointed out is that the projects, new for that concrete area, repeatedly appeared in almost every LAG. Similar situation of applying innovations 
was also observed in Spain, as Esparcia Pérez (2000) claims, in terms of concrete projects, the ability of Leader to inspire 'innovative' actions appears to have been limited.

Monitoring and evaluation are two final stages of the delivery mechanism for the Leader approach. Regarding supreme monitoring and evaluation, majority of the key success factors mentioned before should be monitored such as:

- usage of local resources,

- innovativeness,

- involvement of different stakeholders, different sectors,

- participation in the cooperation projects and networking,

- all the key actors operating in the territory should be involved in evaluation.

The conducted focus groups implied that monitoring as a process strictly follows the compulsory framework given by the EU and that evaluation as such is missing, what could be seen as one of major obstacles preventing fluent transition towards CLLD. Evaluation of outcomes is not only the end of the process, but also it is the beginning of the next stage. Solid foundations are built on coherent, complete and exhaustive knowledge of the results of the past. If there is no evaluation across the whole spectrum, it indicates that the program is subsidy driven, since there is not confirmation that the money is spent as desired and contracted. An institutionalization of the evaluation process, with a bottom up approach is key for the next programming period

Concerning evaluation, another important remark is the selection process for LAGs. Currently, the record and achievements of LAGs are not taken into consideration for their approval for the next programming period. The evaluation mechanism of past achievements is not a point that benefits the selection of LAGs. Giving a fair opportunity for every call for proposals is important, but what then is the incentive for clear and effective results if the past achievements are not taken into account? The evaluation of results and achievements of LAGs plus the positive weighting of those, for the selection of LAGs, will help address many of the obstacles, and create a higher level of readiness of the stakeholders for CLLD.

\section{Conclusions}

The conducted research showed several findings, regarding readiness of the Slovak stakeholders for the CLLD. When describing the results according to the principles of the Leader approach, we could conclude that the "area based" feature was maintained; furthermore, there exists the sense of ownership and belonging in the local communities. On the other hand, linking of individual regional strategies in order to create a bigger picture would be essential. Additionally, more effective usage of marketing tools could also bring some positive changes into the current situation.

The "bottom up" aspect is clearly presented at the local level, however, the links between local and national levels are questionable. This situation could be enhanced by better-tailored, institutionalized consultation between stakeholders.

Requirement for public-private partnership in the territory was formally met, although, the participation of the private sector was not as significant. The new programming period could bring changes, as it will allow wider share of measures accessible for private beneficiaries. Yet, it should be pointed out, that supported public projects undoubtedly have brought effects for more stakeholders in the territory - spill over effect. Lack of inclusion of minority groups in the LAGs could be seen as a serious shortcoming of this aspect and it should definitely be addressed in the future.

Regarding multi-sectorial design, the Leader as such provided a great opportunity for satisfying this feature, however, it was not used to its best potential. More integration between individual policies could cause further development of this feature in the future.

The innovative aspect of the delivery mechanism was also satisfied only partially. Even though, the implemented projects possessed some innovative characteristics, what was missing is 
a comprehensive, unified understanding of innovation together with some systematic tackling of this aspect. An opportunity can be seen in deeper involvement of LAGs in networks fostering new ideas and new innovation such as European Innovation Partnership.

The research proved that networking, as another feature of the Leader, is well developed within the LAGs, however, the relationship between LAGs seem to be more of competitive than cooperative nature. This fact consequently decreases the "voice" of LAGs, furthermore, the National Rural Network, as formal mediator between LAGs and MA, does not operate as expected. The situation could be improved by creation of a LAGs' lobby body or improvement of communication and trust towards the National Rural Network.

Cooperation between LAGs, as the last characteristic feature, was perceived as very essential for future development of LAGs, mainly through exchange of knowledge and learning from others. What is missing within this aspect, however, is the lack of incentive for cooperation of Slovak LAGs in mutual evaluation of their performance. This could positively affect their future performance as well as accountability of the whole approach in the Slovak conditions.

One additional but crucial shortcoming of the delivery mechanism is the public procurement procedure, which prevented its fluent implementation horizontally throughout all the features. The recommendation in this case would be a simplified procedure especially for smaller projects.

In a conclusion, even though the study revealed several weaknesses of Leader implementation in the Slovak conditions, we have a strong belief that majority of them can be addressed in the new programming period. The LAG representatives seemed to understand and accept the essence of the approach as such and the effects of their effort can be already seen in the territory. Therefore, we believe that local stakeholders in the rural Slovakia have solid foundation for acceptance and successful implementation of the community-led local development.

\section{References}

[1] Bumbalová, M., Takáč, I., Valach, M. \& Tvrdoňová, J. (2015). Leader - Ex-Post Evaluation of the Delivery Mechanism. EU Agrarian Law, 4(1), 10-17. DOI: 10.1515/eual-2015-0002.

[2] Commission Implementing Regulation (EU) No. 808/2014 of 17 July 2014 Laying down rules for the application of Regulation (EU) No. 1305/2013 of the European Parliament and of the Council on support for rural development by the European Agricultural Fund for Rural Development (EAFRD).

[3] Copus, A., Courtney, P., Dax, T., Meredith, D., Noguera, J., Talbot, H. \& Shucksmith, M. (2011). European Development Opportunities for Rural Areas - Applied Research 2013/1/2 [Final Report] Luxembourg: ESPON \& UHI Millennium Institute.

[4] Council Regulation (EC) No. 1698/2005 of 20 September 2005 on support for rural development by the European Agricultural Fund for Rural Development (EAFRD).

[5] Dax, T., Strahl, W., Kirwan, J. \& Maye, D. (2013). The Leader programme 2007 - 2013: Enabling or disabling social innovation and neo- endogenous development? Insights from Austria and Ireland. European Urban and Regional Studies, 23(1), 56-68. DOI: $10.1177 / 0969776413490425$.

[6] Dax, T. \& Oedl-Wieser, T. (2016). Rural innovation activities as a means for changing development perspectives - An assessment of more than two decades of promoting LEADER initiatives across the European Union. Studies in Agricultural Economics 118, 30 37. DOI: 10.7896/j.1535.

[7] Esparcia Pérez, J. (2000). The LEADER Programme and the Rise of Rural Development in Spain. Sociologia Ruralis, 40(2), 200 - 207. DOI: 10.1111/1467-9523.00142.

[8] European Commission (2006). Prístup LEADER - základný sprievodce. Luxemburg: Úrad pre vydávanie úradných publikácií Európskych spoločenstiev. 
[9] European Commission (2013). Rural development in the European Union - Statistical and Economic Information - Report 2013 [online], [cit. 2015-01-21]. Available online: http://ec.europa.eu/agriculture/statistics/rural-development/2013/full-text_en.pdf.

[10] European Commission (2015). Community- Led Local Development [online], [cit. 2015-1123]. Available online: http://enrd.ec.europa.eu/en/themes/clld.

[11] Gasior-Niemiec, A. \& Pawlowska, A. (2014). Local Self- Government as an Architect of Coalitions for Local Development. Revija za Univerzalno Odličnost, 3(4), A1 - A17.

[12] Gkartzios, M. \& Scott, M. (2013). Placing Housing in Rural Development: Exogenous, Endogenous and Neo-Endogenous Approaches. Sociologia Ruralis, 54(3), 1-25. DOI: 10.1111/soru.12030.

[13] Goytia, C. N., Todaro-Rivera, L., Brenner, B., Shepard, P., Piedras, V. \& Horowitz, C. (2013). Community Capacity Building: A Collaborative Approach to Designing a Training and Education Model. Progress in Community Health Partnerships: Research, Education, and Action, 7(3), 291-297. DOI: 10.1353/cpr.2013.0031.

[14] Grambličková, M., Melichár, J., Mojžiš, M., Paulíniová, Z., Tižíková Nemcová, R. \& Zamkovský, J. (2013). Prístup CLLD a LEADER v programovom období $2014-2020$ [unpublished study]. Available online: at http://www.priateliazeme.sk/cepa/images/collector/collection/publikacie/sprava_clld_finalpdf

[15] Kovách, I. (2000). LEADER, a New Social Order, and the Central- and East-European Countries. Sociologia Ruralis, 4(2), 181-189. DOI: 10.1111/1467-9523.00140.

[16] McAreavey, R. (2009). Community regeneration: an elite or 'real' community space? International Planning Studies, 14(3), 311-327. DOI: 10.1080/13563470903481627.

[17] Miller, S. (2014). Emerging Trends and Challenges in Community - Led Local Development (CLLD). European Structural and Investment Funds Journal, 2(4), 302-307.

[18] Národné pol'nohospodárske a potravinárske centrum. Záverečné a hodnotiace správy k úlohe technickej pomoci: Priebežné (ongoing) hodnotenie Programu rozvoja vidieka SR 2007-2013 [online], [cit. 2015-11-23]. Available online: http://www.vuepp.sk/04_ongoing.htm.

[19] Nevěděl, L. \& Horák, M. (2015). Operation of the Selected Local Action Groups. Acta Universitatis Agriculturae et Silviculturae Mendelianae Brunensis, 63(1), 347-352.

[20] Owen, D. \& Vercruysse, J. P. (2014). Community Driven Development and Community- Led Local Development. European Structural and Investment Funds Journal, 2(č), 308-318.

[21] Peters, R. (2013). Investing in Europe's Future at Grassoots Level: The Role of EU Funded Community Led Local Development (CLLD). European Structural and Investment Funds Journal 1(1), 27-30.

[22] Regulation (EU) No 1303/2013 of the European Parliament and of the Council of 17 December 2013 laying down common provisions on the European Regional Development Fund, the European Social Fund, the Cohesion Fund, the European Agricultural Fund for Rural Development and the European Maritime and Fisheries Fund and laying down general provisions on the European Regional Development Fund, the European Social Fund, the Cohesion Fund and the European Maritime and Fisheries Fund and repealing Council Regulation (EC) No 1083/2006.

[23] Shucksmith, M. (2000). Endogenous development, social capital and social inclusion: perspectives from LEADER in the UK. Sociologia Ruralis, 40(2), 208-218. DOI: 10.1111/1467-9523.00143.

[24] Shucksmith, M. (2012). Future Directions in Rural Development Executive Summary. Dunfermline: Andrew Carnegie House.

[25] Volk, A. \& Bojnec, Š. (2014). Local action groups and the LEADER co-financing of rural development projects in Slovenia. Agricultural Economics, 60(8), 364-375.

[26] Tvrdoňová, J. (2009). Hodnocení strategií místního rozvoje venkova a strategií/záměrů 
v rámci př́istupu Leader a jejich institucionální zabezpečení. Praha: UZEI. 